INSTITUT AGAMA ISLAM IMAM GHOZALI (IAIIG) CILACAP

LPPM (Lembaga Penelitian dan Pengabdian Masyarakat)

Al-Munqidz: Jurnal Kajian Keislaman

Jl. Kemerdekaan Barat No.17 Kesugihan-Cilacap || https://ejournal.iaiig.ac.id/index.php/amk Issn SK no. : 0005.235/Jl.3.2/SK.ISSN/2012.07 || 0005.27158462/Jl.3.1/SK.ISSN/2020.01

\title{
STUDI ISLAM DALAM KACA MATA NORMATIF DAN HISTORIS
}

\author{
Muhammad Fauzil 'Adzim', Nela Syarah Vrikati \\ Pascasarjana UIN Sunan Kalijaga Yogyakarta \\ E-mail: fauziladzim27@gmail.com ${ }^{1}$, $\underline{\text { nelasyarahvrikati@gmail.com }}^{2}$
}

Naskah Diterima

27 Agustus 2020

Publis Artikel

7 September 2020
Abstrak: Artikel ini ingin membahas bagaimana Islam dikaji dari kacamata keilmuan bukan dari sisi kayikinan. Islam dikaji dari segi pengetahuan menggunakan ilmu yang sering kita sebut sebagai Islamic Studies. Islamic studies ini sebagai pisau analisa dalam memahami Islam dari sisi pengetahuan bukan dari sisi keyakinan. Dalam islamic studies ini juga ada beberapa cara pandang dalam memahami Islam di anataranya ada segi normatif dan segi historis. Normatif ini adalah acara pandang sarjana muslim dalam mengkaji Islam dari segi teks, yang mana teks ini (al-Quran dan Sunnah) untuk memantapakan keyakinan mereka terhadap Islam itu sendiri. Untuk menguatkan segi nash (teks) maka diperlukan sisi historis dalam mengkaji Islam. historis menjadi penting dalam mengkaji Islam karena menguatkan, dan memantapkan eksistensi Islam itu sendiri dalam kancah ilmu pengetahuan.

\section{Kata Kunci: Islamic Studies, Normatif, Historis}

\section{A. Pendahuluan}

Islam merupakan agama penutup, dimana Islam sebagai agama yang mengacu dan bersumber pada wahyu Allah. Agama Islam diyakini dapat menjamin terwujudnya kehidupan manusia yang sejahtera lahir dan batin. Hal ini tidak hanya berlaku pada pemeluknya saja, melainkan juga mensejahterakan pemeluk agama lain. Dimana Islam tidak hanya pada jalur horizontal (hubungan dengan Allah), akan tetapi memiliki jalur vertikal (hubungan dengan manusia).

Kehadiran agama saat ini dituntut secara aktif terlibat dalam memecahkan masalah yang dihadapai oleh manusia. Agama disini tidak boleh hanya sekedar sebagai lambang keshalehan, melainkan secara konsepsional yang menunjukka cara apa saja yang paling efektif dalam 
memecahkan masalah. ${ }^{1}$ Tetapi bagi sebagian masyarakat, tidak mudah untuk memahami agama Islam secara mendalam. Pemahaman ajaran Islam yang tidak utuh menyebabkan keracunan sehingga dalam praktek ajaran Islam hanya dilihat dari satu aspek saja. ${ }^{2}$

Dalam memahami Islam perlu menggunakan studi keilmuan, salah satunya Islamic studies. Pada saat ini telah memberikan kontribusi besar terhadap pemahaman masyarakat terhadap Islam tersendiri. Studi Islam disini memiliki cakupan makna, pemebagian dan juga aspek yang berbeda-beda. Namun titik tekan kajian terletak pada ajaran Islam yang sepenuhnya diambil dari Alquran dan Hadis secara murni.

Maka perlu adanya pengkajian pendekatan yang digunakan dalam memahami Islam. Karena melalui pendekatan dalam pengkajian Islam ini secara fungsional dapat dirasakan oleh umat Islam. Dan sebaliknya tanpa mengetahui pendekatan, tidak mustahil agama akan terlihat sulit dipahami dan dirasakan oleh masyarakat. Timbullah masyarakat akan mencari pemecahan masalah kepada selain agama, yang hal ini tidak boleh terjadi.

Dalam studi Islam itu terdapat pendekatan untuk memahami dan mengkaji keilmuan keislaman, diantara terdapat pendekatan normatif dan historis. Pendekatan normatif dalam memahami agama dengan menggunakan kerangka ilmu ketuhanan yang bertolak dari suatu keyakinan. Sedangkan pendekatan historis lebih dalam memahai sesuatu dengan melihat, memahami dan menghubungkan suatu peristiwa atau kejadian masa lalu berdasarkan fakta dan data yang sebenarnya.

Dengan demikian, melalui tulisan ini penulis akan mengkombinasikan pendekatan normatif dan historis dalam pengkajian keislaman baik yang berhubungan dengan ajaran, sejarah maupun praktik plaksanakannya. Karena kedua pendekatan tersebut tidak dapat terpisahkan satu sama lain dan menjadi satu kesatuan yang utuh.

\section{B. Metode}

Metode ini menggunakan metode kualitatif yang bersifat kepustakaan atau library research. Sumber dalam penelitian ada dua. Sumber primer dan sumber sekunder. Sumber primer bersasal dari buku-buku sekunder yang berkaitan dengan Islamic studies sedangkan sumber sekunder penunjang dari sumber primer berupa buku, jurnal, dan artikel.

\footnotetext{
${ }^{1}$ Abuddin Nata, Metodologi Studi Islam, (Jakarta: Rajawali Pres, 2009), hlm. 27.

${ }^{2}$ Dede Ahmad Ghazali dan Heri Gunawan, Studi Islam, (Bandung Remaja Rosdakarya, 2015), hlm. 13.
} 


\section{Pembahasan}

1. Studi Islam dalam Kacamata Normatif

Pendekatan normatif dalam studi Islam merupakan suatu presepsi dari seseorang dalam menemukan, memahami, serta menjelaskan suatu keilmuan keislaman. Pemahaman Islam ini memberikan penilaian atas seseuatu berdasarkan norma (ayat Alquran dan hadis) secara tekstual yang belum ada campur tangan manusia.

Pendekatan normatif memiliki domain (ranah) yang bersifat keimanan, tanpa melakukan kritik. Pendekatan ini mengosumsi seluruh ajaran Islam (Alquran dan Hadits) sebagai suatu kebenaran yang hakiki, harus diterima dan tidak bisa dinganggu gugat. ${ }^{3}$ Dengan menggunakan kerangka Ketuhanan yang mengacu dari suatu keyakinan, hal ini mengakibatkan seseorang beranggapan bahwa dirinya merasa paling benar dibanding dengan yang lain. ${ }^{4}$

Menurut Amin Abdullah, pendekatan normatif ini memiliki karakteristik yaitu kecenderungan untuk mengutamakan loyalitas terhadap kelompok sendiri, adanya keterlibatan pribadi dan penghayatan yang begitu kental kepada ajaran-ajaran teologi yang diyakini kebenarannya, mengungkapkan perasaan dan pemikiran dengan menggunakan bahasa yang bersifat subjektif yakni bahasa sebagai pelaku bukan sebagai pengamat. ${ }^{5}$

Pemahaman Islam secara normatif bersifat doktriner yaitu dengan menjadikan Islam sebagai objek studi yang diyakini sebagai sesuatu yang suci berasal dari Tuhan yang mempunyai nilai kebenaran mutklak, absolut dan universal. ${ }^{6}$ Sebagai contoh yaitu turunnya Alquran yang merupakan aspek normatif Islam kedudukannya adalah absolut, sehingga kebenaran yang ada di dalam Alquran merupakan kebenaran pasti.

Disisi lain dari kacamata normatif terdapat teori yang digunakan secara bersamaan dengan pendekatan normatif. Yang pertama yaitu teroi yang bertujuan untuk mengetahui

\footnotetext{
${ }^{3}$ Masdar Hilmi dan Muzakki, Dinamika Baru Studi Islam, (Surabaya: Arkola, 2015), hlm 63-64.

${ }^{4}$ Dede Ahmad Ghazali dan Heri Gunawan, Studi Islam..., hlm. 65.

${ }^{5}$ Amin Abdullah, Studi Agama Normativitas atau Historisitas?, Cet. V, (Yogyakarta: Pustaka Pelajar, 2011),
} hlm. 14.

${ }^{6}$ Muhaimin, Kawasan dan Wawasan Studi Islam, (Jakarta: Kencana, 2007), hlm. 14. 
kebenaran yang dapat dibuktikan secara empirik dan eksperimental. Teroi yang kedua yaitu suatu hal yang sulit dibuktikan secara empirik dan eksperimental. ${ }^{7}$

Teroi mengacu pada hal-hal yang dapat dibuktikan secara empirik biasanya terkait permasalahan yang berhubungan dengan penalaran ( $\left.r a^{\prime} y i\right)$. Sedangkan hal-hal yang tidak berhungan dengan empirik biasanya dibuktikan dengan mendahulukan kepercaan. Akan tetapi tidak mudah untuk menentukan hal-hal yang masuk dalam klarifikasi emprik dan tidak empirik, sehingga terjadi perbedaan pendapat. Maka disini memerlukan pendekatan normatif yang kritis.

Maka dengan ini dalam Alquran telah mengantisipasi kemungkinan timbulnya sikap dan budaya saling menyalahkan dan merendahkaan kelompok. Tindakan tersebut yang menjadi cikal bakal dan sumber konflik sosial yang potensial. Maka Alquran mengingatkan dalam Surah al-Hujurat ayat 11.

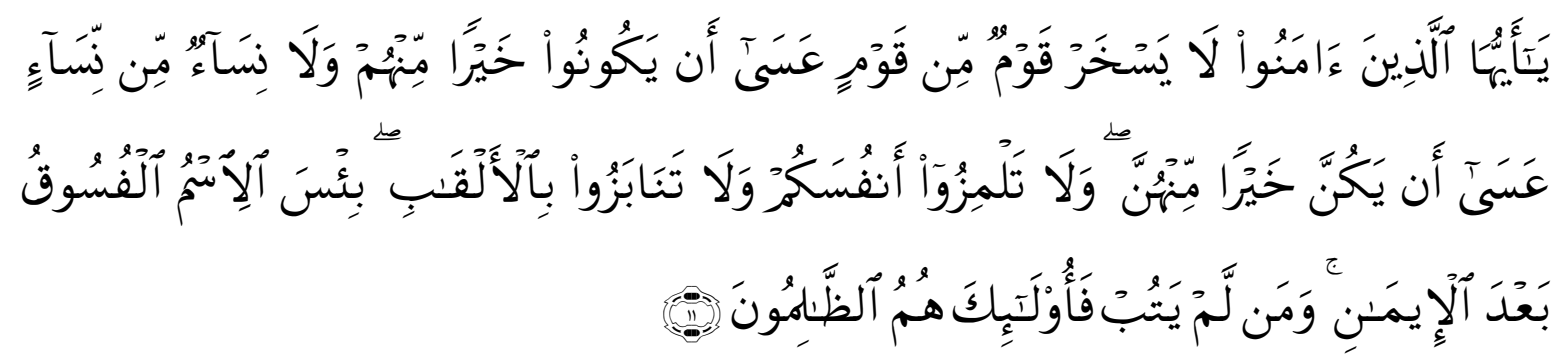

Artinya: Hai orang-orang yang beriman, janganlah sekumpulan orang laki-laki merendahkan kumpulan yang lain, boleh Jadi yang ditertawakan itu lebih baik dari mereka. dan jangan pula sekumpulan perempuan merendahkan kumpulan lainnya, boleh Jadi yang direndahkan itu lebih baik. dan janganlah suka mencela dirimu sendiri dan jangan memanggil dengan gelaran yang mengandung ejekan. seburuk-buruk panggilan adalah (panggilan) yang buruk sesudah iman dan Barangsiapa yang tidak bertobat, Maka mereka Itulah orangorang yang zalim.

Dalam memahami dan memaknai Islam, kalangan yang berpaham normatif berusaha melakukan proyek Arabisasi dalam sebuah organisasi Islam di seluruh dunia. Dalam pandangan mereka, pemahaman Islam otentik adalah Islam yang dicontohkan oleh para salafussholih dan pemahaman yang tidak bercampur dengan warna dan budaya lokal.

${ }^{7}$ Hasbullah dan Hadia Martanti, Problematika Memahami Agama Islam (Antara Normativitas dan Historisitas), Jurnal: el_Huda, Vol. 11, No. 1, 2020, hlm. 138. 
Karena itu, keberagaman atau keunikan bereksprsi dalam beragama itu tidak dekat dengan karakter Arab dan bahkan bertentangan dengan Islam yang otentik. ${ }^{8}$

Hal ini bertolak dengan konteks Islam yang dibawa oleh Wali Songo ke Nusantara dan dikembangkan oleh organisasi sosial keagamaan yang mengapresiasi terhadap budaya lokal. Yang mana pandangan ini menurut kaum normatif telah menghilangkan nilai-nilai keaslian Islam semenjak berakulturasi dengan budaya lokal.

Dalam pemahaman dan praktik keagamaan Islam otentik yang termanifestasikan dalam semangat purifikasi (permurnian) dan radikalisme atau fundamentalisme keagamaan. Hal ini muncul tidak hanya berbentuk ide dan gagasan akan tetapi berwujud sebuah gerakan yang menampilkan keberagamaan Islami dan kaffah yang diberlakukan di seluruh dunia.

Islam dalam pandangan mereka harus sesuai dengan pola yang teleh diterapkan oleh kalangan terdahulu dan Islam telah menjadi suatu doktrin yang sudah sempurna dan tidak memerlukan inovasi sehingga kita tinggal melakukan secara apa adanya. Maka biasanya mereka memiliki paham penafsiran yang tertutup. ${ }^{10}$

Dalam pendekatan normatif memiliki kelebihan yaitu melalui pendekatan normatif, seseorang akan memiliki sikap militansi dalam bergama, yakni berpegang teguh terhadap agama yang diyakini atas kebenarannya, tanpa memandang dan meremehkan agama lainnya. Seseorang akan memiliki sikap fanatis terhadap agama yang dianutnya. ${ }^{11}$ Serta membuat agama yang dianut menjadi sederhana dan lebih mudah diamalkan serta tidak menghilangkan kesakralan agama itu sendiri.

Sedengkan kelemahannya yaitu seseorang akan memiliki sifat eksklusif dan tidak mau mengakui kebenaran agama lain. Karena jika Jika seseorang meyakini sesuatu dengan kebenaran yang mutlak, maka seseorang tersebut akan menjadi pribadi tertup, tidak mau menerima pendapat serta pemahaman orang lain. ${ }^{12}$

${ }^{8}$ Edi Susanto, Pendidikan Agama Islam; Antara Tektual Normatif dengan Kontekstual Historis, Jurnal: Tadris, Vol. 4, No. 2, 2009, hlm. 176. 2004).

${ }^{9}$ Jamhari dan Jajang Jahroni, Gerakan Salafi Radikal di Indonesia, (Jakarta: Raja Grafindo Persada dan PPIM,

${ }^{10}$ Sun Choirul Ummah, Akar Radikalisme Islam di Indonesia, Jurnal: Humanika, No. 12, 2012, hlm. 117.

${ }^{11}$ Abuddin Nata, Metodologi Studi..., hlm. 46.

${ }^{12}$ Abuddin Nata, Metodologi Studi..., hlm. 46. 
Kemudian seseorang cenderung manganggap bahwa pokok ajaran yang harus diterima sebagai hal yang benar dan baik, tidak boleh dibantah dan diragukan, dan seseorang akan mempersempit ruang dialog dengan agama lain. Seseorang itu hanya akan berdialog kepada orang yang berkeyakinan Islam, karena beranggapan bahwa selain agama Islam itu salah.

Pada sisi lain, membuat Islam terputus dari tradisi dan khazanah intelektual Muslim yang sedemikian kaya. Banyak dimensi peradaban dan warisan budaya Islam klasik serta budaya masyarakat yang disikapi secara kaku sebagai sesuatu yang tidak islami. Sebagai akibatnya, akan membuat Islam kurang responsif dalam mensikapi kebutuhan dan persoalan lokal, yang antara satu dengan yang lain berbeda sekaligus sangat beragam.

2. Aplikasi Pendekatan Normatif dalam Studi Islam

Penerapan pendekatan normatif dalam studi Islam dapat dilihat pada pemahaman terhadap nash (al-Qur'an). Dalam memahaami nash (al-Qur'an) banyak teori-teori yang telah digunakan oleh para fuqoha (ahli fikih), ushuliyyin (ahli usul fikih), muhadditsin (ahli hadits), mufassirin (ahli tafsir), diantaranya adalah dengan teori teologis-filosogis yaitu pendekatan memahami Islam dengan cara menafsirkan secara logis-filosofis (mencari nilai-nilai objektif dari subjektifitas al-Qur'an). ${ }^{13}$

Teori lain adalah normatif-sosiologis atau sosio-teologis, sebagaimana yang ditawarkan Asghar Ali Engerineer dan Tahir al-Haddad, yakni dalam memahami nash ada pemisahan antara nash normatif dengan nash sosiologis. Nash normatif adalah nash yang tidak tergantung pada konteks. Sementara nash sosiologis adalah nash yang dalam pemahamannya harus disesuaikan dengan konteks, waktu, tempat, dan konteks lainnya. ${ }^{14}$

Contoh pendekatan normatif dalam realita di kehidupan sekarang ini seperti peringatan "Maulidan", yakni sebuah acara peringatan untuk mengenang kelahiran Nabi Muhammad saw. yang dilakukan dengan berbagai cara yang berbeda antara satu kelompok dengan yang lainnya. Untuk format acaranya antar satu daerah dengan daerah yang lain cukup beragam, ada yang dengan membaca manaqib, al-Barzanji. Hampir setiap tahunnya acara peringatan ini dimeriahkan diberbagai daerah di Indonesia, bahkan di dunia.

\footnotetext{
${ }^{13}$ Khoiruddin Nasution, Pengantar Studi Islam (Yogjyakarta: Academia, 2010), hlm. 190.

${ }^{14}$ Khoiruddin Nasution, Pengantar Studi Islam..., hlm 191.
} 
Hingga saat ini mengenai acara peringatan tersebut masih menjadi isu-isu keagamaan yang menjadi bahan perbincangan dalam tiap tahunnya, pada bulan Rabi'ul Awal tepatnya. Tidak cukup sampai di situ, dampak dari perbedaan pemahaman mengenai boleh tidaknya mengadakan acara "maulidan" tersebut bahkan sampai pada titik saling mengklaim "benar" dan "salah" atau "bid'ah".

Mahrus Ali mengutip dari Abdul Aziz bin Abdillah bin Baz (pernah menjadi ketua majelis ulama' besar Saudi dan mufti Makkah) mengemukakan, bahwa peringatan maulid sekalipun itu maulid Nabi seluruhnya adalah bid'ah, kemungkaran, diada-adakan oleh manusia dan tidak terdapat pada masa Nabi, para sahabat atau di abad-abad yang utama. Menurutnya peringatan semacam ini adalah bagian dari tasyabbuh dengan kebudayaan Nasrani dan Yahudi untuk memperingati hari besar mereka, walaupun banyak orang yang melakukannya. Ia menyatakan bahwa ukuran kebenaran bukan karena banyak orang yang mendukung, tapi ada tidaknya dalil-dalil dari al-Qur'an dan al-Sunnah yang menjelaskan. ${ }^{15}$

Abdul Aziz bin Abdillah bin Baz dalam memberikan ketegasan terhadap hukum bid'ah yang menyesatkan pada peringatan maulid Nabi merupakan contoh implementasi dari pendekatan normatif dalam memahami agama Islam. Karena ia membangun argumentasinya dengan melandaskan pada al-Qur'an dan al-Sunnah. Perayaan maulid Nabi saw. itu tidak ditemukan baik secara tersurat maupun secara tersirat dalam dua skrip utama agama Islam tersebut. ${ }^{16}$

Memahami Islam secara normatif berarti menggali, memahami, menghayati dan mengamalkan pesan-pesan Islam yang bersumber dari al-Qur'an dan al-Sunnah. Jadi segala sesuatu baik yang berupa ritual keagamaan atau tidak yang tidak berlandaskan dua referensi utama tersebut dianggap menyalahi ajaran Islam yang sebenarnya.

Dengan memahami urian di atas, tidak bisa kita dikatakan salah dalam memahami agama dengan menggunakan pendekatan normatif. Karena nomatifitas agama ini akan mendorong masyarakat untuk selalu memegang teguh nilai-nilai universal yang ada dalam agamanya dan seseorang akan memiliki sikap militansi dalam bergama.

Namun menyikapi setiap permasalahan yang muncul di masyarakat dengan hanya menggunakan pendekatan normatif juga tidak bisa dibenarkan. Karena paradigma normatif

\footnotetext{
${ }^{15}$ Arif Shaifudin, Makana Islam dalam Pendekatan Noematif, El-Wasathiya Jurnal Studi Islam, Vi. 5, No. 1, Juni 2017, hlm. 11.

${ }^{16}$ Arif Shaifudin, Makana Islam dalam..., hlm. 12.
} 
yang berisi doktrin ketat yang mengharuskan agama muncul sebagai kekuatan absolut dapat memicu gesekan antar kelompok atau organisasi masyarakat. Maka harus memerlukan pendekatan lain, yang menjadikan Islam sebafai agama yang dinamis dan lunak terhadap perbedaan yang sudah menjadi realitas masyarakat Indonesia.

3. Studi Islam dalam Kacamata Historis

Dalam studi Islam pendekatan historis ini sangat dibutuhkan dalam memahami agama dalam hal ini agama Islam. Karena agama itu sendiri turun dalam situasi yang konkret bahkan berkaitan dengan kondisi sosial kemasyarakatan. ${ }^{17}$ Pendekatan historis dalam memahami ajaran Islam berusaha menekankan pada agama Islam sebagai agama normatif yang berasal dari Tuhan kemudian diakomodasikan kedalam kebudayaan yang berasal dari manusia dengan tanpa menghapus indentitasnya. ${ }^{18}$

Studi Islam dengan pendekatan historis ini dapat membantu masyarakat Islam agar konsisten dengan norma-norma agama sekaligus mampu menghadapi dan mengantisipasi dalam permasalahan yang ada. Serta dapat mengkaji Islam dari umat Islam bahkan juga selain Islam masa lalu dan masa sekarang untuk kepentingan masa akan datang. ${ }^{19}$

Pendekatan historis merupakan cara pandang cara pandang dalam memahami sesuatu dengan melihat, memahami dan menghubungkan suatu peristiwa atau kejadian berdasarkan data dan fakta agar bermanfaat masa yang akan datang. Pendekatan ini tidak dapat lepas dari histotris yang berkembangan di masyarakat karena Islam turun dalam rangka memberikan petunjuk kepada manusia dan hampir keilmuan dalam Islam terkait dengan sejarah.

Dalam pendekatan historis terdapat aliran yang digunakan dalam mengkaji Arab pra-Islam, kelahirann Islam dan penaklukan Islam atau secara umum kajian Islan dan masyarakat Islam. Aliran pertama yang digunakann oleh para tradisionalis yang disebut pendekatan tradisonal dan aliran kedua disebut pendekatan revisionis.

Pendekatan tradisionalis ini dalam parakteknya membatasi diri, hanya pada warisan literatur Arab-Muslim dengan pemahaman yang menggunakan premis-premis yang berkembang dalam tradisi keagamaan Islam. Pada prinsipnya, pendekatan ini didasarkan

\footnotetext{
${ }^{17}$ Dede Ahmad Ghazali dan Heri Gunawan, Studi Islam...., hlm. 72.

${ }^{18}$ Abdurrahman Wahid, Pergulatan Negara, Agama dan Kebudayaan (Jakarta: Desantara, 2001), hlm. 111.

${ }^{19} \mathrm{M}$ Ardi Kusumawardana, Upaya Pengembangan Kajian Islam Melalui Pendekatan Sejarah, el-Jikmah Jurnal: Kajian dan Penelitian Pendidikan Islam, Vol. 14, No. 1, 2020, hal. 118.
} 
pada asumsi-asumisi dan premis-premis dasar yaitu dengan literatur Islam, sanad keilmuan, data tulisan tidak perlu dibuktikan degan proses analisa peristiwa sejarah, Alquran dianalisa berdasarkan tradisi yang berkembang dalam kalagan ilmuwan Islam dan analisis linguistik. ${ }^{20}$

Pendekatan tradisionalis ini pola pemikiran yang hanya mengandalkan sumbersumber tertulis, itu pun dibatasi hanya sumber-sumber dari umat Islam yang berbahasa Arab dengan menggunakan pola-pola pendekatan, teori dan metodologi yang berkembang dikalangan umat Islam.

Pendekatan revisionis ini didasarkan pada asumsi-asumisi dan premis-premis dasar yaitu melalui sumber tertulis yang universal, saksi sejarah, reduksi penulisan karena keterbatasan kata yang meggambarkan peristiwa yang benar-benar terjadi, sejarah tentang tranmisi dokumen tertulis harus dicermati, karya tulis belum pasti mengungkapkan apa yang benar-benar terjadi atau hanya menyajikan pandangan penulisnya tentang suatu peristiwa yang diketahui dan bukti eksternal merupakan hal penting untuk diteliti. ${ }^{21}$

Pendekatan revisionis pada dasarnya bertumpu pada tiga hal: pertama, pendekatan kritik sumber terhadap al-Qur'an dan literatur Islam terkait dengan kebangkitan Islam, penaklukan Islam; kedua, pentingnya membandingkan literatur Islam dengan data eksternal di luar tradisi umat Islam; ketiga pemanfaatan bukti material yang semasa dengan peristiwa yang diteliti dan kesimpulan yang diambil dari data yang tidak semasa, yakni data berupa literatur Islam yang ditulis jauh setelah peristiwa terjadi.

Pendekatan historis dalam studi Islam ditanggapi positif oleh beberapa tokoh seperti Mohammad Arkount yang menawarkan kajian Islam melalaui pendekatan historis. Beliau seorang pemikir pos-tradisionalistik yang mengkaji keotoritasan teks. Baginya teks suci dan tradisi tidak dapat dipisahkan dari historitas, melainkan justru sepenuhnya terbentuk dan terbukaan dalam sejarah.

Meskipun pendekatan historis berasal dari Barat namun bukan berarti tidak dapat diterapkan pada studi Islam. Akan tetapi pendekatan ini dapat diterapkan pada semua

\footnotetext{
${ }^{20}$ Minhaji, Sejarah Sosial dalam Studi Islam Teori, Metodologi dan Impelentasi, (Yogyakarta: Sunan Kalijaga Press, 2013), hlm. 99-101.

${ }^{21}$ Minhaji, Sejarah Sosial dalam Studi Islam, hlm. 102-108.
} 
sejarah umat manusia dan bahkan dalam hal menafsirkan wahyu sekalipun membutuhkannya dengan menghubungkan konteks historis turunya wahyu. ${ }^{22}$

Kemudian Fazlurrahman mengatakan dalam memahami Islam tidak akan berhasil tanpa diikuti oleh pemahaman yang konprehensif dalam perspektif kesejarahannya, serta menunjukkan bahwa pengetahuan sejarah sebagai alat utama dalam pengkajian Islam. ${ }^{23}$

Dengan ini pendekatan historis ini mengambil semangat yang telah diajarkan oleh Wali Songo dalam dakwahnya ke Nusantara sekitar abad 15 dan ke tanah jawa pada abad 16. Dalam hal ini Wali Songo telah berhasi mengakulturasikan nilai-nilai lokal dalam Islam yang khas keindonesiaan dan tidak ada nalar Arabisasi yang melekat dalam penyebaran Islam awal di Nusantara.

Dalam konteks ini sudah jelas bahwa Walisongo tidak melakukan pemurnian dan otentifikasi ajaran Islam secara total, melainkan melalui adaptasi terhadap budaya dan kondisi sosial masyarakat setempat. Sehingga masyarakat Nusantara tidak melakukan aksi perlawanan terhadap ajara baru yang masuk dan dapat menerima dengan damai.

Dengan demikian Islam tidak dapat lepas dari kesejarahan manusia dalam ruang dan waktu. Melalui pendekatan historis seorang diajak berfikir dari alam idealis menuju alam yang bersifat empris dan mendunia. Dan seseorang dalam memahami agama dapat menyesuaikan dalam kondiasi yang dihadapai dan bersifat terbuka, dapat menerima masukan pendapat dari luar.

4. Aplikasi Pendekatan Historis dalam Studi Islam

Pendekatan historis dalam studi Islam menurut Ali Syari'ati yang menganalogikan pendekatan historis sebagai tokoh dalam mengkaji Islam. Menurutnya dalam mengkaji seorang tokoh yang harus mengetahui pemikirannya melalui karya-karya, kemudian dikaji juha biografi tokoh dalam rangka memahami, antara lain; korelasi antara ide-ide yang tertuang dalam karya-karya tulisnya dengan aktivitas kesehariannya. Dari situ bisa dilihat konsistensi antara ide pada satu sisi dengan praktik pada kehidupan sisi lain. ${ }^{24}$

Berdasarkan analogi Ali Syariati diatas, dalam studi Islam ada beberapa hal yang harus dilakukan yakni dengan mengkaji Alquran sebagai pedoman hidup umat Islam dan sebagai sumber pokok ajaran Islam. Kemudian menelaah sejarah Islam dengan menelaah

\footnotetext{
${ }^{22}$ Adnin Armas, Metode Bible dalam Studi al-Qur'an, (Jakarta: Gema Insan, 2005), hlm. 66.

${ }^{23}$ Minhaji, Sejarah Sosial dalam Studi Islam...., hlm. 3.

${ }^{24}$ Ali Syariati, On The Sociology of Islam, (Berkeley: Mizan Press, 1979), hlm. 39-69.
} 
bagaimana Alquran itu dipahami dan diamalkan dalam sejarah umat Islam sejak masa Rasulullah hingga sekarang.

Dalam hal ini setidaknya terdapat empat argumen yaitu Pertama, Tuhan telah memilih bahasa (arab) sebagai komunikasi anatara Tuhan dengan Rasulullah. Kedua, keterlibatan Rasulullah sebagai penerima wahyu dan disisi lain Rasulullah sebagai penafsir serta ikut menentukan proses sosial pengujaran dan tekstualisasi Alquran. Ketiga, Alquran turun berdialog dengan realitas kehidupan. Keempat, wahyu telah ditulis dalam bentuk teks dan direkan dalam hafalan seseorang. ${ }^{25}$

Dengan demikian terdapat hubungan dialog anatara Alquran dengan realitas budaya kehidupan. Maka tradisi keagamaan dapat berubah sesuai dengan konteks sosial dan kultural suatu masyarakat. Atas dasar itu, bagi kalangan ini, Islam yang hadir di setiap jengkal bumi ini selalu merupakan produk racikan-dialektik antara wahyu dan tradisi, sehingga Islam yang ideal sebagaimana dibayangkan kalangan Islam otentik itu sebenarnya tidak ada. Yang ada adalah Islam yang riil,yang hidup ditengah masyarakat yang plural ini.

\section{Kesimpulan}

Islam sebagai agama yang hanif bisa diterima dikalangan masyarakat dalam dua term yang berbeda. Pertama, dalam kancah Islam sebagai dogma yakni berdasarkan keyakinan ritual keagamaan sehari-hari. Kedua, Islam sebagai ilmu yang dikaji oleh kalangan akademisi yang ingin mencari tau Islam dari segi ilmu pengetahuan. Dalam kancah ini Islam dikaji dalam ilmuilmu keislaman atau yang kita sebut sebagai Islamic Studies.

Islamic studies menjadi term yang menarik dalam mengkaji Islam. dalam islamic studies banyak sekali pendekatan yang digunakan dalam memahami Islam di antaranya ada pendekatan normatif dan pendekatan historis. Pendekata normatif untuk memahami teks yang bersifat dogmatis. Di mana melalui pendekatan ini diharapkan ummat Islam bertambah keyakinannya terhadap Islam tanpa adanya keraguan.

Di samping pendekatan normatif, sebagai pengkaji keislaman harus mengetahui sisi-sisi historis dalam Islam. maka pentimg kiranya dalam hal ini pendekatan historis harus dikaji dan dipahami dalam mengkaji Islam yang berkaitan dengan sejarah Islam sendiri. Implikasinya terletak pada marwah Islam sendiri tatkala dikaji dari sisi historisitas.

\footnotetext{
${ }^{25}$ Edi Susanto, Pendidikan Agama Islam...., hlm. 184.
} 


\section{Daftar Pustaka}

Abdullah, Amin. Studi Agama Normativitas atau Historisitas?. Cet. V. Yogyakarta: Pustaka Pelajar. 2011.

Ahmad, Dede \& Heri Gunawan, Studi Islam. Bandung: Remaja Rosdakarya. 2015.

Armas, Adnin. Metode Bible dalam Studi al-Qur'an. Jakarta: Gema Insan. 2005.

Hasbullah \& Hadia Martanti, Problematika Memahami Agama Islam (Antara Normativitas dan Historisitas). Jurnal: el_Huda. Vol. 11. No. 1. 2020.

Hilmi, Masdar \& Muzakki. Dinamika Baru Studi Islam. Surabaya: Arkola. 2015.

Jamhari \& Jajang Jahroni. Gerakan Salafi Radikal di Indonesia. Jakarta: Raja Grafindo Persada dan PPIM. 2004.

Kusumawardana, Ardi. Upaya Pengembangan Kajian Islam Melalui Pendekatan Sejarah. elJikmah Jurnal: Kajian dan Penelitian Pendidikan Islam. Vol. 14. No. 1. 2020.

Minhaji. Sejarah Sosial dalam Studi Islam Teori, Metodologi dan Impelentasi. Yogyakarta: Sunan Kalijaga Press. 2013.

Muhaimin. Kawasan dan Wawasan Studi Islam. Jakarta: Kencana. 2007.

Nasution, Khoiruddin. Pengantar Studi Islam. Yogjyakarta: Academia., 2010.

Nata, Abuddin. Metodologi Studi Islam. Jakarta: Rajawali Pres. 2009.

Shaifudin, Arif. Makana Islam dalam Pendekatan Noematif. El-Wasathiya Jurnal Studi Islam. Vol. 5. No. 1. Juni 2017.

Susanto, Edi. Pendidikan Agama Islam; Antara Tektual Normatif dengan Kontekstual Historis. Jurnal: Tadris. Vol. 4. No. 2. 2009.

Syariati, Ali On The Sociology of Islam. Berkeley: Mizan Press. 1979.

Ummah, Sun Choirul. Akar Radikalisme Islam di Indonesia. Jurnal: Humanika. No. 12. 2012.

Wahid, Abdurrahman. Pergulatan Negara, Agama dan Kebudayaan. Jakarta: Desantara. 2001. 